\title{
Keeping More than Home Fires Burning: Prairie Women During the Second World War
}

\author{
Meagan Breault*
}

\begin{abstract}
The Second World War proved to be a pivotal time for women across Canada. With men away defending the nation, it was women who were expected to not only 'keep the home fires burning' but also keep the nation stable. In order to do that, women had to move into roles that were traditionally reserved for men. On the prairies, women picked up the slack readily, moving into factory positions in Central Canada, taking over the family farm, and even joining the army in the Women's Corps. For the women of Alberta, Saskatchewan, and Manitoba, this new role provided them with the chance to earn their own finances for the first time. The war also established a precedent that women could work and be good mothers at the same time. The work that prairie and Canadian women did during the war, helped normalize the idea of women in the workplace that is so prevalent in today's society.
\end{abstract}

Keywords: Canada, women, war, work, prairies

On March 24, 1942, Prime Minister William Lyon Mackenzie stated that Canadian women were "the most important available reserve of manpower. ${ }^{11}$ With many men enlisting to fight overseas, the responsibilities of the household and family were often left to their female counterparts. In addition to familial responsibilities, it became acceptable for women to work outside of the home during the Second World War as they were needed to help supply the war effort. Women became the necessary "manpower," as

1. Jean Bruce, Back the Attack! Canadian Women During the Second World War, at Home and Abroad (Toronto: Macmillan of Canada, 1985), 55.
Prime Minister Mackenzie stated, to fill positions typically reserved for men. The conditions of the Second World War required women in Canada, particularly from prairies, to step into masculine positions in industries such as manufacturing and agriculture. While prairie women are often overlooked the history of women's labour during the war, they contributed much of the labour necessary to keep "the home fires burning. ${ }^{2}$ Prairie women added to the war effort by migrating to Ontario to take up positions in

2. "Women At War," Veterans Affairs Canada, last modified November 27, 2017,

http://www.veterans.gc.ca/eng/remembrance/history/historicalsheets/women.

*Department of History, College of Arts and Science, University of Saskatchewan, Saskatoon, SK, Canada

Correspondence:mlbo45@mail.usask.ca 
factories, by working on farms during seeding and harvesting seasons, and by joining the women's divisions of the army, navy or air force such as the Canadian Women's Army Corps.

During the Second World War, Canadian women became a major source of labour for the manufacturing of war munitions and supplies. While there were few wartime factories located in the prairie provinces of Alberta, Saskatchewan, and Manitoba, Western women were still being impacted by the women's labour movement. In the decade leading up to the Second World War, the Great Depression had been a major source of hardship for prairie farming communities. ${ }^{3}$ Also known as the Dirty Thirties, the Great Depression devastated the Canadian prairies on account of the provinces' economies being rurally and agriculturally based. ${ }^{4}$ Western farmers struggled for over a decade as drought and grasshoppers destroyed crops, and the world wheat market remained unstable. ${ }^{5}$ Nevertheless, the establishment of wartime factories gave women across the prairies an opportunity to make a steady income -- that is, if they were willing to move to the factories in Central Canada. ${ }^{6}$ A significant number of women migrated from Manitoba and Saskatchewan looking for wartime work.? In addition, the National Selective Service worked in partnership with recruiters from manufacturing plants in Quebec and Ontario, and, as a result, women from Winnipeg, Edmonton, Calgary, Saskatoon and Regina were transferred to Central Canada. ${ }^{8}$

In "The Politics of 'Selective' Memory: Re-Visioning Canadian Women's Wartime Work in the Public Record," Pamela Wakewich and Helen Smith argue that the Canadian Car and Foundry (Can Car) aircraft manufacturing war plant in Fort William, Ontario provided local and national employment to Canadian women during the war. ${ }^{9}$ Wakewich and Smith argue that many prairie women,

3. Pamela Wakewich and Helen Smith, "The Politics of 'Selective' Memory: Re-Visioning Canadian Women's Wartime Work in the Public Record," Oral History Society 34, no. 2 (2006): 60, http://www.jstor.org/stable/40179897.

4. Gerald Friesen, The Canadian Prairies: A History (Toronto: University of Toronto Press, 1984), 182.

5. Friesen, 184.

6. Wakewich and Smith, "The Politics of 'Selective' Memory," 60.

7. Helen E. Smith and Pamela Wakewich, "Regulating Body Boundaries and Health During the Second World War: Nationalist Discourse, Media Representations and the Experiences of Canadian Women War Workers," Gender \& History 24, no. 1 (March 26, 2012): 58, http://dx.doi.org/ 10.1111/j.1468-0424.2011.01668.x.

8. Ruth Pierson, "Women's Emancipation and the Recruitment of Women into the Canadian Labour Force in World War II," Historical Papers 11, no. 1 (1976): 150.

9. Wakewich and Smith, "The Politics of 'Selective' Memory," 56. especially those from Saskatchewan, seized the opportunity to migrate and work at a factory like Can Car. For example, Marta (no last name was given), a Polish immigrant, became responsible for two sisters and a brother, making her the sole breadwinner of the family after the deaths of both parents. ${ }^{10}$ Marta struggled to maintain the family farm in Saskatchewan during the Great Depression because her work as a seamstress was simply not enough. ${ }^{11}$ However, in 1944 she decided to migrate to Fort William to work at the Can Car war plant where she could use the higher wages to provide for her brother, who was in the Navy, and help pay for her sister's nursing career. ${ }^{12}$ Marta said:

Had it not been for this war there would have been an awful lot of people that would not have got out of all those little [Prairie] farms... And there was an awful lot of hardships at that time because there was no work and then all of a sudden all this opened up for them and it was really, really a great thing... In my memory I thought I was a millionaire. ${ }^{13}$

For Saskatchewan and prairie women like Marta, the establishment of wartime factories opened the door for women to make their first real wages. Given that the Great Depression had devastated the prairies, working in wartime factories gave women a chance to take back control over their lives and their finances.

With the high number of women working outside of the home during the Second World War, several provinces including Ontario, Quebec, and Alberta looked into providing wartime day nurseries partially funded by the federal government. ${ }^{14}$ Ontario and Quebec were already partnering with the federal government to fund day nurseries in their provinces, and between August of 1943 and March of 1944 it seemed as though the Alberta Social Credit Government under Ernest C. Manning would follow suit. ${ }^{15}$ The women's and social service organizations of Alberta argued that day nurseries would solve issues of child neglect, labour shortages, juvenile delinquency, and child development. ${ }^{16}$ However, in May 1944, Manning's

10. Wakewich and Smith, 60.

11. Wakewich and Smith, 60.

12. Wakewich and Smith, 60.

13. Wakewich and Smith, 60.

14. Tom Langford, "Why Alberta Vacillated Over Wartime Day Nurseries," Prairie Forum 28, no. 2 (2003): 173.

15. Langford, 173.

16. Langford, 173. 
government abandoned the plan for day nurseries. ${ }^{17}$ Despite this failure to enact the plan, Alberta was the only other province, aside from Ontario and Quebec, to consider the cost-sharing agreement with the federal government. Many women, however, supported the provision of day nurseries. One women's group in Edmonton conducted a door-to-door survey in one small neighbourhood, and found at least 27 women in need of childcare. ${ }^{18}$ Since local, provincial, and federal governments were pushing women to "[r]oll up their sleeves to victory, ${ }^{\prime 19}$ the need for some sort of childcare was obvious. In the end, there was a rising fear that women working outside the home would lead to issues such as juvenile delinquency and the Alberta government abandoned their plans to create a day nursery system. ${ }^{20}$

Given that Alberta, Saskatchewan, and Manitoba were largely farming- and ranching-based economies, the agrarian work needed to continue throughout the war, particularly since the agricultural goods were vital to the supply of the Allied troops in Europe. In a letter designed to recruit female workers, the director of the National Selective Service program stated that "there must be no let up in the supply of vital arms and equipment -- no let up in food production -- no let up in the essential services." ${ }^{21}$ Because the production of agricultural goods was deemed such a high priority, male and female workers needed a special permit before they could transfer to a different job, unless that job was in the armed forces. ${ }^{22}$ Since the vast majority of men had enlisted, leaving their farms without the labour needed to sustain them, wartime recruiters turned to women to fill the gap. ${ }^{23}$ All across the prairies, wives and daughters of farmers took over the work on farms so that their husbands and sons could enlist and fight overseas. ${ }^{24}$ Women willing to work the soil freed up able bodied men for enlistment. If these women had not taken over the agrarian work, men would have either had stay and work their farms to provide food for the war effort or abandon the land in order to serve, which would result in

17. Lisa Pasolli, “I ask you, Mr. Mitchell, is the emergency over?': Debating Day Nurseries in the Second World War," Canadian Historical Review 96, no. 1 (March 2015): 21, muse.jhu.edu/article/576248.

18. Pasolli, 21-22.

19. Bruce, Back the Attack!, 55.

20. Pasolli, "'I ask you, Mr. Mitchell," 22.

21. Ruth R. Pierson, They're Still Women After All: The Second World War and Canadian Womanhood (Toronto: McClelland and Stewart, 1986), 44.

22. Bruce, Back the Attack!, 123.

23. Pierson, They're Still Women After All, 32.

24. Pierson, 32. less food for the war effort. The labour of women in agriculture made it possible for both food production and male enlistment into the army to occur simultaneously. The July 31,1942, issue of the Saskatoon Star Phoenix newspaper included a story titled "Need Womenfolk to Help Farmers, Officials Claim." ${ }^{25}$ While many of the positions advertised were for cooks and kitchen girls, the article indicated that farmers were looking for women to work in the fields for harvest. ${ }^{26}$ In the article, Professor E.A. Hardy, an agricultural engineer from the University of Saskatchewan, outlined the kinds of agricultural work that could be done by women, such as binding and stooking the wheat, as well as the running of machinery. ${ }^{27}$ The article concluded by requesting that all women who felt they would be capable of farm work file applications with the Unemployment Insurance Commission in the National Trust Building. ${ }^{28}$ This advertisement reinforces the idea that women were needed to perform essential jobs throughout war. It also implies that women were capable for male labour and for the sake of the war effort should be allowed to perform such tasks.

Not only was there a demand for women's labour in the agricultural sector, but women were also being permitted to enlist in the Canadian Armed Forces for the first time in Canada's history. On August 13, 1941, the Canadian Women's Army Corps was formed as a way to alleviate the pressure for more troops. ${ }^{29}$ With the exception of nurses, women were not at the front lines, yet they took over vital roles in the army so that men could be freed for combat. Women's roles included: telephone operators and messengers; drivers of light vehicles; mess women and canteen helpers; typists, stenographers and clerks at training centers and camps; and cooks in messes and hospitals. ${ }^{30}$ Approximately 50,000 women enlisted in the Second World War. ${ }^{31}$ They, however, did not serve equally throughout the armed forces. Military groups such as the Royal Canadian Air Force and the Women's Royal Canadian Naval Service had restrictions that allowed only women

25. "Need Womenfolk to Help Farmers, Officials Claim," Saskatoon Star Phoenix, July 31, 1942.

26. "Need Womenfolk to Help Farmers."

27. "Need Womenfolk to Help Farmers."

28. "Need Womenfolk to Help Farmers."

29. Bruce, Back the Attack!, 37.

30. Bruce, 37.

31. James Wood, “Canadian Women's Army Corps," The Canadian Encyclopedia, last modified December 21, 2015, http://www.thecanadianencyclopedia.ca/en/article/canadianwomens-army-corps/. 


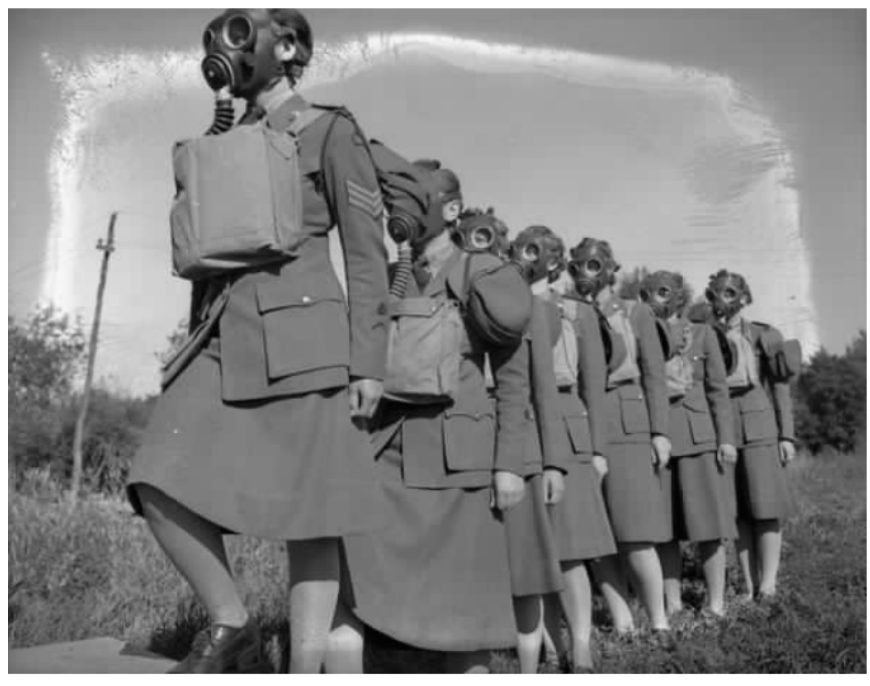

Figure 1: "Personnel entering a gas chamber during a training exercise, No.2 Canadian Women's Army Corps (C.W.A.C.) (Basic) Training Centre, Vermilion, Alberta, Canada, July 1943," Library and Archives Canada.

who were "British subjects"132 of "white race"133 to enlist. In contrast, the Canadian Women's Army Corps welcomed "any citizen of [the] United Nations." ${ }^{134}$ This policy led many women in the prairies who were often of immigrant or First Nations status to enlist. For example, Mary Greyeyes of the Muskeg Lake Reservation in Saskatchewan became the first Aboriginal woman to enlist in the Canadian Army in July of $1942 .{ }^{35}$ The Canadian Women's Army Corps. was a crucial role that allowed women from the prairie provinces to help with the war effort while shifting societal boundaries.

Alberta played a significant role in the training of female recruits, as one of the two basic training camps for the Canadian Women's Army Corps. was located in the province. At the base in Vermillion, women participated in courses that were anywhere from two weeks to six months in duration. They learned about everything from drilling to training for gas attacks. ${ }^{36}$ Figure 1 , "Personnel entering a gas chamber during a training exercise, No.2 Canadian Women's Army Corps (C.W.A.C.) (Basic) Training Centre, Vermilion, Alberta, Canada, July 1943," a photograph taken by Ken Bell, depicts women wearing gas masks while

32. Julie Anne Redstone-Lewis, “The Creation of the Women's Royal Canadian Naval Service and Its Role in Canadian Naval Intelligence and Communications, 1939-45," (master's thesis, Wilfrid Laurier University, 2007), 53, http://scholars.wlu.ca/etd/45.

33. Pierson, They're Still Women After All, 113.

34. Pierson, 113.

35. Pierson, 113.

36. Bruce, Back the Attack!, 38. drilling. ${ }^{37}$ Their uniform suggests the ambivalence toward women in the armed forces. On one hand, the women are wearing military jackets that are of a very similar fashion to the men's. Yet, the women are still wearing skirts to signal their feminity and therefore their difference from their male counterparts. Their dress reveals the tensions between the masculinist culture of the army and the desire for women to remain feminine.

Many women embraced their role in the armed forces. In Back the Attack! Canadian Women During the Second World War, at Home and Abroad by Jean Bruce, Western women are shown to be enthusiastic participants in the war, particularly on account of their role in the army. The women of the Canadian Women's Army Corps. in Alberta were often known to sing a short song entitled "Mademoiselle from Armentieres" to show their commitment to war. The lyrics are as follows:

\section{We're the girls who joined the CWACs to beat the Huns, \\ We're the girls behind the boys behind the guns, We're the girls who help the men, We teach them all the tricks but then We're the CWACs from Alberta. ${ }^{38}$}

The song demonstrated that Albertan women were ready to take up the call to serve and defend the nation against the Germans. Yet, the song also establishes that women played a supporting role: they were "behind the boys behind the guns," they "help[ed] the men" and "[taught] them all the tricks." ${ }^{139}$ Nonetheless, the song shows that the female soldiers were proud of where they came from and wanted to present Albertan women as real contributors to the war effort.

At the end of the war, although the government thanked Western and Canadian women for their contributions, the women's skills were no longer needed. With the return of around 750,000 soldiers after the Second World War, both the government and male populations sought to place women back inside the home. $4^{4^{\circ}}$ At a convention in 1943, a delegate of the Trades and Labour congress was quoted as saying that "women have no business in industry, except in wartime. After the war women are going to be in competition with their fathers,

37. Ken Bell, "Personnel entering a gas chamber during a training exercise, No.2 Canadian Women's Army Corps (C.W.A.C.) (Basic) Training Centre, Vermilion, Alberta, Canada, July 1943," Library and Archives Canada, MIKAN 3205994, IN 477, July 1943.

38. "Mademoiselle from Armentieres" quoted in Bruce, Back the Attack!, 46.

39. "Mademoiselle from Armentieres."

40. Pierson, They're Still Women After All, 215. 
sons, and future husbands. ${ }^{\prime{ }^{41}}$ By the 1950s, the federal government stressed female femininity and emphasized that a woman's place was in the home as a "homemaker. ${ }^{142}$ They encouraged women to leave the workforce by barring women from civil service jobs, cutting funds for child care, denying women tax exemptions, and running a public campaign that encouraged employers to hire male veterans over other candidates. ${ }^{43}$

The Second World War catapulted women into the workforce, and despite the immediate postwar rhetoric that the woman's proper place was in the home, the percentage of married women drastically increased as the decades passed. In 1941 less than five percent of married women worked outside of the home; by 1961 that number rose to 21 percent, and by 1975 it rose again to 41 percent. ${ }^{44}$ The Second World War demonstrated that women were capable of providing labour outside of the home - even in jobs that were traditionally thought to be men's jobs. In addition, the contribution of women to the Canadian Armed Forces during the Second World War led to permanent changes in the way in which the army conducted itself. In 1951, the Canadian Government approved a proposal to enlist women in the militia, which ensured the continued role of women aiding in the defense of the nation. ${ }^{45}$ Although women were not permitted to participate in combat roles, servicewomen actively participated in the army through finance; medical and dental care; communications; administration-, supply-, and shore--based operations. ${ }^{46}$ At a meeting in 1971, the Minister of National Defense said that within the Canadian Forces there would be no limitations on the employment of women with the exception of sea-going service, service in remote locations, and primary combat roles. ${ }^{47}$ In 1983, women represented 8.3 percent of the total personnel in the Canadian Armed Forces and received the same pay as the men. ${ }^{48}$ As of February 2016, women represented 15 percent of the Canadian Armed Forces, and 3.9 percent of those women participated in combat occupations such as artillery,

41. Bruce, Back the Attack!,159.

42. Joan Sangster, Transforming Labour: Women and Work in Post-War Canada (Toronto: University of Toronto Press, Scholarly Publishing Division, 2010), 16.

43. Sangster, 18.

44. Sangster, 19.

45. Hugh W. Conrod, Athene, Goddess of War: The Canadian Women's Army Corps - Their Story (Dartmouth: Writing \& Editorial Services, 1983), 375.

46. Conrod, 381.

47. Conrod, 381.

48. Conrod, 382-383. infantry, and combat engineering..$^{49}$ The Second World War truly was a pivotal time for women in the Armed Forces. After the end of the Second World War, women from all across the country, including the Prairies, have been able to enlist and serve their country.

The Second World War saw a major influx of Prairie women into the workforce. Just as during the First World War, with men away at the front, Canada relied on women to keep the home fires burning in more ways than one. Women from Alberta, Saskatchewan, and Manitoba played a vital role in the war effort. Prairie women began to migrate to other parts of the country to work in munitions and wartime factories. They were encouraged to help farmers by working in the fields during seeding and harvest. For the first time in Canadian history, women were allowed to enlist in the army through the Canadian Women's Army Corps. The conditions which the Second World War set into action helped reinforce the idea that women could work outside of the home. Without that fundamental experience, women may not have entered into the workforce, earned their own money, or have had many more opportunities to explore the world on their own terms.

49. "Women in the Canadian Armed Forces," Department of National Defence and the Canadian Armed Forces, last modified September 30, 2016, , http://www.forces.gc.ca/en/news/article.page?doc=women-in-thecanadian-armed-forces/ildcias0. 


\section{Bibliography}

\section{Primary Sources}

Bell, Ken. "Personnel entering a gas chamber during a training exercise, No.2 Canadian Women's Army Corps (C.W.A.C.) (Basic) Training Centre, Vermilion, Alberta, Canada, July 1943," Library and Archives Canada, MIKAN 3205994, IN 477, July 1943.

Saskatoon Star Phoenix. "Need Womenfolk to Help Farmers, Officials Claim." July 31, 1942.

\section{Secondary Sources}

Bruce, Jean. Back the Attack! Canadian Women During the Second World War, at Home and Abroad. Toronto: Macmillan of Canada, 1985.

Conrod, Hugh W. Athene, Goddess of War: The Canadian Women's Army Corps - Their Story. Dartmouth: Writing \& Editorial Services, 1983.

Friesen, Gerald. The Canadian Prairies: A History. Toronto: University of Toronto Press, 1984.

Langford, Tom. "Why Alberta Vacillated Over Wartime Day Nurseries." Prairie Forum 28, no. 2 (2003): 173-94.

Pasolli, Lisa. "'I ask you, Mr. Mitchell, is the emergency over?': Debating Day Nurseries in the Second World War." Canadian Historical Review 96, no. 1 (March 2015): 1-31. muse.jhu.edu/article/576248.

Pierson, Ruth. "Women's Emancipation and the Recruitment of Women into the Canadian Labour Force in World War II." Historical Papers 11, no. 1 (1976): 141-73.

Pierson, Ruth R. They're Still Women After All: The Second World War and Canadian Womanhood. Toronto, Ont.: McClelland and Stewart, 1986.

Redstone-Lewis, Julie Anne. "The Creation of the Women's Royal Canadian Naval Service and Its Role in Canadian Naval Intelligence and Communications, 1939-45." Master's thesis, Wilfrid Laurier University, 2007. http://scholars.wlu.ca/etd/45.

Sangster, Joan. Transforming Labour: Women and Work in Post-War Canada. Toronto: University of Toronto Press, Scholarly Publishing Division, 2010.
Smith, Helen E. and Pamela Wakewich. "Regulating Body Boundaries and Health During the Second World War: Nationalist Discourse, Media Representations and the Experiences of Canadian Women War Workers." Gender \& History 24, no. 1 (March 26, 2012): 56-73. http://dx.doi.org/10.1111/j.1468-0424.2011.01668.x

Wakewich, Pamela and Helen Smith. "The Politics of 'Selective' Memory: Re-Visioning Canadian Women's Wartime Work in the Public Record." Oral History Society 34, no. 2 (2006): 56-68. http://www.jstor.org/stable/40179897.

Wood, James. "Canadian Women's Army Corps." The Canadian Encyclopedia. Last modified December 21, 2015. http://www.thecanadianencyclopedia.ca/en/article/ca nadian-womens-army-corps/.

"Women At War." Veterans Affairs Canada. Last modified November 27, 2017. http://www.veterans.gc.ca/eng/remembrance/history/ historical-sheets/women.

"Women in the Canadian Armed Forces." Department of National Defence and the Canadian Armed Forces. Last modified September 30, 2016.

http://www.forces.gc.ca/en/news/article.page?doc=wo men-in-the-canadian-armed-forces/ildciaso. 
Prairie Women's Work During Wartime (Breault)

University of Saskatchewan Undergraduate Research Journal 